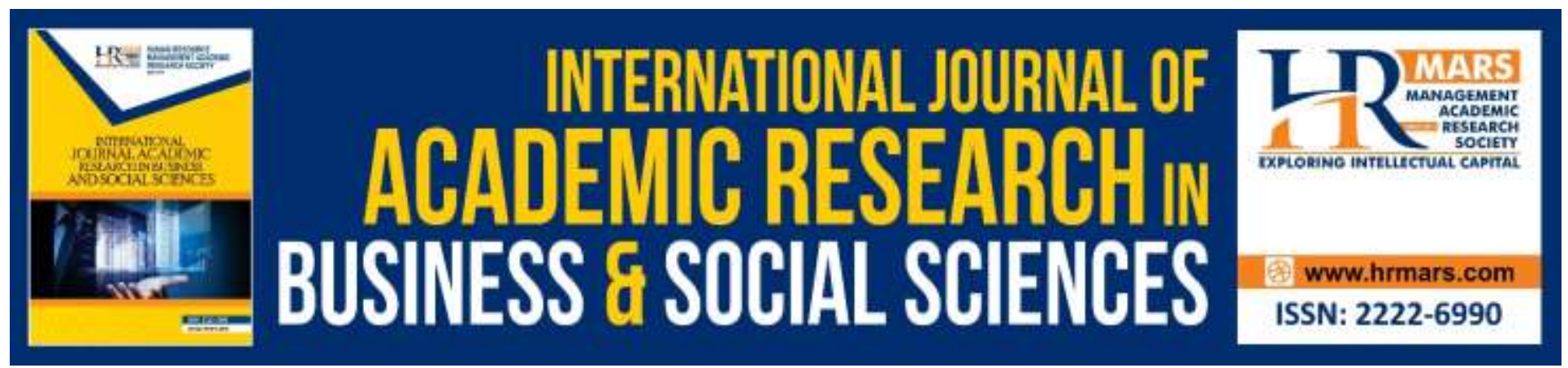

\title{
The Study on The Development of Asnaf fisabilillah by The Islamic Religious Council of Malacca
}

Shahrul Hilmi Bin Othman, Aizul Bin Mohd Ismon, Mohd Fauzan Fahurruzi

To Link this Article: http://dx.doi.org/10.6007/IJARBSS/v10-i2/6929

DOI:10.6007/IJARBSS/v10-i2/6929

Received: 03 January 2019, Revised: 28 January 2020, Accepted: 02 February 2020

Published Online: 19 February 2020

In-Text Citation: (Othman et al., 2020)

To Cite this Article: Othman, S. H. Bin, Ismon, A. B. M., \& Fahurruzi, M. F. (2020). The Study on The Development of Asnaf fisabilillah by The Islamic Religious Council of Malacca. International Journal of Academic Research in Business and Social Sciences, 10(2), 294-302.

Copyright: @ 2020 The Author(s)

Published by Human Resource Management Academic Research Society (www.hrmars.com)

This article is published under the Creative Commons Attribution (CC BY 4.0) license. Anyone may reproduce, distribute, translate and create derivative works of this article (for both commercial and non-commercial purposes), subject to full attribution to the original publication and authors. The full terms of this license may be seen at: http://creativecommons.org/licences/by/4.0/legalcode

Vol. 10, No. 2, 2020, Pg. 294 - 302

http://hrmars.com/index.php/pages/detail/IJARBSS

JOURNAL HOMEPAGE

Full Terms \& Conditions of access and use can be found at http://hrmars.com/index.php/pages/detail/publication-ethics 


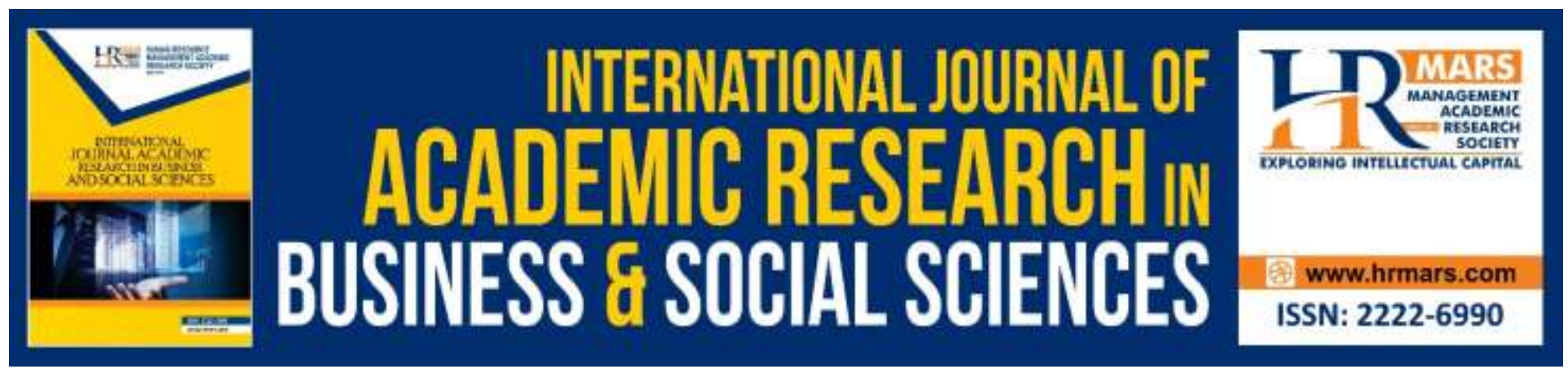

\title{
The Study on The Development of Asnaf fisabilillah by The Islamic Religious Council of Malacca
}

\author{
Shahrul Hilmi Bin Othman \\ Head of Department Foundation Programme, Centre of Foundation Programme and General \\ Studies, University College of Islam Melaka. \\ Email: shahrul@kuim.edu.my.
}

Aizul Bin Mohd Ismon

Lecturer of the Faculty of Islamic Knowledge, University College of Islam Melaka.

Email: aizulismon@kuim.edu.my

\author{
Mohd Fauzan Fahurruzi \\ Faculty of Islamic Knowledge, University College of Islam Melaka
}

\begin{abstract}
This study is to explain distribution of zakat and development recipient zakat include Asnaf Fisabilillah. The development of the asnaf fisabilillah implemented by the State Islamic Religious Council of Malacca (MAIM). The study was conducted using an interview approach that involved face-to-face interactions with officers in the distribution unit. This study is to explain distribution of zakat and development Asnaf Fisabilillah. The development of the asnaf fisabilillah implemented by the State Islamic Religious Council of Malacca (MAIM). The study was conducted using an interview approach that involved face-to-face interactions with officers in the distribution unit. The findings of this study show that there is no limit on the number of distributions on the probability distribution. The distribution is not focused on individuals such as poor indigenous people, rather, donations will be made in the form of aid or donations to institutions and NGOs and mosque management to carry out missionary activities, welfare and social programs. In addition, financial contributions are also provided to orphanage management. In addition, the zakat distribution is also focused on human capital development and entrepreneurship of the Asnaf.
\end{abstract}

Keywords: Zakat, Collection Zakat, Distribution Zakat, Asnaf Zakat, Management Asnaf Fisabilillah

\section{Introduction}

Zakat is one of the important instruments in the Islamic economy that serves as a strong source of funding to ensure that every goal is achieved and to ensure justice and social stability through 
INTERNATIONAL JOURNAL OF ACADEMIC RESEARCH IN BUSINESS AND SOCIAL SCIENCES Vol. 10, No. 2, Feb, 2020, E-ISSN: 2222-6990 @ 2020 HRMARS

society. Through the obligation of zakat, Islam has created a caring and responsible attitude in every Muslim so that they care about those in need. Islam has elevated the status of zakat recipients where the burden of responsibility to help them has been passed on to Muslims who are capable of fulfilling their duties. Zakat privileges itself as a backbone to the structure of the Islamic economic system in the development of comprehensive socio-economies. Therefore, every qualified person should be able to meet the demands of this third Islamic pillar by engaging in zakat production and distribution activities. If this claim is ignored, then the sustainability and superiority of the zakat instrument in establishing the welfare of the people will not be fully realized. Through the charity system, the socioeconomic gap between the rich and poor can be bridged through the realization of the ability of the needy that the needy also have certain rights and shares in their wealth

Melaka Islamic Religion Council (in Malay word is Majlis Agama Islam Melaka) was founded on September 28, 1960. It is intended to manage the affairs of the Islamic State of Malacca in addition to assist and advise His Majesty the Yang di-Pertuan Agong. Establishment of Melaka Islamic Religion Council strengthened by the enactment of the establishment of: Administration of the Religion of Islam (State of Malacca) 2002 Section 4 subsection 1. There shall be a body known as the "Majlis Agama Islam Melaka" to assist and advise the Yang di-Pertuan Agong in matters relating to Islam. As a policy-making body Agama Islam Negeri Melaka, some agencies / institutions Islam was established as the Islamic Religious Department, Mufti Department, Syariah Court and subsidiaries Melaka Islamic Religion Council to implement the decisions or policies made by Melaka Islamic Religion Council include Zakat Melaka. Zakat Melaka (PZM) was incorporated in April 2001 where the collection of zakat was placed under the PZM while the zakat distribution was placed under the Baitulmal Council of the Islamic Religious Council of Malacca. Melaka Zakat Center as an Institution entrusted to carry out zakat collection management is always committed to quality services as the core of Malacca Zakat Center management. This has had a positive impact in giving the Muslim community confidence to pay their zakat obligations and thus increase the zakat collection in Malacca.

News reports describing the Melaka Zakat Collection (ZM) increased by 2.59 per cent to RM87.8 million during the year 2018 compared with the same period of RM85.5 million in 2017. The figure showed an increase of RM2.21 million with a total payer of 44,129 people compared with 41,477 in 2017 ie an increase of 2,652 people or 6.39 per cent of that. Zakat collections in 2018 amounted to RM83.8 million, an increase of RM2.13 million over the same period in 2017 of RM81.7 million. As of December 31, 2018, the Melaka Islamic Religious Council had distributed zakat of RM86.9 million over the same period in 2017 of RM80.5 million with an increase of RM6.3 million or 7.92 percent. Subsequently poor Asnaf had the highest expenditure of RM31.1 or 35.83 per cent while the lowest expenditure came from asnaf ibn sabil amounting to RM87,515 or 0.10 per cent. (https://melaka-insider.com/2019/03/06/rm87-8-juta-kutipan-zakat-melaka-naik-25-9). From the above statement, this study is intended to explain the shape of the total distribution of Asnaf fisabillah, and to explain the development Asnaf Fisabillah by Melaka Islamic Religion Council

\section{Literature Review}

Aspects of developing and eradicating poverty are also issues of concern in Islam. One of the steps to make the agenda successful is through the distribution of charity funds to the poor and needy. In the teachings of Islam, it also demands that efforts to eradicate poverty be a duty to the whole 
individual and the private sector. This responsibility is synonymous with the Zakat Institution which is an important institution that promotes the principle of caring for one another and achieving good social status. Zakat worship is one of the five pillars of Islam that has become a duty to Muslims.

Zakat is one of the main economic sources for Islamic countries. Efficient and systematic zakat management can boost the potential of zakat as an instrument of Islamic development. Optimal use of zakat funds is absolutely essential to enhance the quality and potential of every Muslim. In Malaysia, the administration and administration of charity is administered by the Islamic Religious Council in each state, the Islamic Religious Council is responsible for determining the eligibility of beneficiaries as well as the form of assistance appropriate to each recipient's background so that the assistance provided can be utilized as best as possible. Various programs are aimed at enhancing the quality of education through balanced economic distribution, social welfare distribution, human capital production and educational improvement. Therefore, every Muslim in particular the zakat payer should take the opportunity to work with the Islamic Religious Council in ensuring that the proceeds of the zakat fund can be optimized to develop Muslims in Malaysia (Meerangani, 2017).

Ramli \& Abdullah (2016) generally, the collection and distribution of zakat is under the responsibility of the government. However, there is a debate among the fuqaha 'that zakat can be distributed directly from property owners to asnaf. This debate on this issue is closely related to the division of property into outward and inward. found that there are three channels allowed in Islam to distribute charity. First, give the zakat to the government which will then be distributed. Second, distribute zakat directly to asnaf without passing through amil. Third, appoint a representative to distribute the pledge to asnaf.

A comparative study of the efficiency measurement in term of financial management of the State Islamic Religious Council (SIRC) with the performance of the financial and non-financial zakat distribution could open a debate to improve the quality of the institution's management. On the other hand the financial management of SIRC is also important to ensure that the institution could achieve the objectives that have been established. The negative impression of the society still exists in term of zakat distribution and it could affect the level of Muslim's confidence to perform their duties to pay zakat through the zakat institution. The inefficiencies of zakat distribution might be seen through the amount of surplus fund of zakat undistributed every year and the institution not able to distribute the zakat fund to the eighth asnaf as well as not distributed based on the priority of asnaf. The main issue here, is there any long run relationship between financial performance and zakat distribution's performance of SIRC. This study will categorize a financial performance in three (3) parts, namely liquidity, solvency and profitability; While the performance of the zakat distribution will be divided into two (2) parts, namely efficiency of zakat distribution from the financial point of view (surplus of zakat distribution annually) and the non-financial point of view (in term of asnaf priority). This study also examined the patterns of zakat distribution to asnaf by each SIRC every year. A secondary data comprised of several SIRC annual reports were analyzed starting from the year 2000 to 2013. This study analyzes five SIRC in Malaysia, namely MAIS and MAINPP that representing the corporatized zakat institution; MAIJ, MAIDAM and MUIS that representing the non-corporatized zakat institution. The findings reveal that the relationship between the performance of financial management and the performance of zakat (Hairunnizam Wahid, Ahmad, Ali, Nor, \& Rashid, 2017). 
INTERNATIONAL JOURNAL OF ACADEMIC RESEARCH IN BUSINESS AND SOCIAL SCIENCES Vol. 10, No. 2, Feb, 2020, E-ISSN: 2222-6990 @ 2020 HRMARS

In terms of zakat distribution, Islamic law clearly states that zakat should be distributed to eight specific groups. The eight groups are al-fuqara (poor people), al-masakin (poor), amil, muallaf who need to be comforted, al-riqab (servant), al-gharimin (debtors), fi-sabilillah (the one who is fighting in the way of Allah) and finally ibn sabil (the traveler). If amil does not have information on other asnaf or a small amount of zakat collection, many scholars think that zakat should be distributed to at least three zakat, Syafie sect opinion states that four groups should be given priority other than amil is poor, poor, the debtor (al-riqab) and the traveler (ibn sabil) (Wahid, Ahmad, \& Kader, 2009).

According by Mujaini (2005) has reclassified these eight sections into three categories or bases of distribution, i) Distribution based on need. It includes the poor, the poor, the slave, the debtor and the ibn sabil. ii) Distribution based on nurturing and promoting religious and moral life. It includes muallaf and fi-sabilillah. iii) Distribution based on incentives and motivations for charity managers. It includes amyl.

Study by Ibrahim (2008) the collection and distribution of zakat have important socioeconomic implications. Among the main concerns are the distribution of income and wealth, as well as poverty eradication. by using the Gini-Coefficient Index, the zakat distribution has succeeded in reducing income inequality among the poor and needy. Further, by using the Atkinson index it was found that the zakat distribution made the income distribution more unbalanced from 0.38 to 0.53 . The level of welfare of society decreases due to the loss in income due to income imbalance. In conclusion, his study found that zakat distribution was able to reduce poverty, poverty and poverty alleviation as measured by popular poverty indices used by researchers in this field.

From a social point of view, zakat management clearly helps to meet the needs of poor indigenous peoples who make up the majority of countries in the world. Zakat also plays an important role in enhancing the welfare of society where there is a difference between rich and poor. Among the wisdom that zakat implies is that its management is capable of improving the social and moral standing of the community and that it can unite members of the community into one body. In addition, it can also cleanse the soul from the stubbornness and stubbornness. It is also a stronghold of security in the Islamic economic system and a guarantor of its stability and sustainability. In addition, zakat plays a very important role in promoting social justice as there is a wealth distribution among the community where the poor can benefit from the existence of the rich and the rich will contribute to cooperation. If the wealth was to be used to alleviate poverty, there would certainly be harmony and love between the rich and the poor. This shows the importance of helping one another in Islamic rule (Rahman, Basah, Abdullah, Nooh, \& Fauzi, 2014).

Zakat is closely linked to the al-Shari'ah maqasid and the well-being of the community where it is ordained by God with the ultimate goal of providing social security for the poor and needy, promoting balanced economic growth in society, and also as a form purification of the soul. Socioeconomically, the role of zakat has two implications: income distribution (zakat) and eradication of poverty. Islam does not want that wealth to be monopolized by one person or only a few, but it must be distributed among other people, especially those who need it most. Therefore, it is appropriate that some of the property is issued in the form of a zakat obligation to meet the demands of Shari'ah. At the same time, Islam also takes seriously the problem of poverty that is affecting the lives of the people. Thus, zakat plays an important role in eradicating poverty from poverty. In order to realize the well-being of the people through the distribution of zakat it is 
necessary for the Muslims to realize their zakat when their conditions are met. It is not possible for the well-being to be realized if the beneficiary of the zakat is not aware of his obligation to issue zakat. In addition to the management of charity distribution by charity or charity charity charities it is also essential for the charity to be effective and right on target (Haron \& Rahman, 2016).

in a study (Hairunnizam, Sanep, \& Mohd Ali, 2004) the effect of charity aid by charity institutions on the quality of life of poor and poor people by using primary data through questionnaires in Jerantut, Pahang, Taiping, Perak and Sandakan districts, Sabah. This study estimates the likelihood of a charity recipient being whether or not they are satisfied with their quality of life as a result of receiving a charity using a logit model. The study found that charity aid has a significant impact on the quality of life of the poor especially in education and social inclusion. Some important implications are proposed in this paper to ensure that the quality of life of the poor is not neglected in the current state of development.

The findings of (Ali, Ibrahim, Aziz, \& Johari, 2014) study explaining the disadvantages of the zakat distribution method are that First by, it does not take into account the difference in cost of living between urban and rural areas. Second, the gender requirements of different households are not addressed in the calculation of the Zakat Poverty Line (Kifayah Limit). To make zakat assistance a significant impact on the quality of life of the poor and needy, a drastic action must be taken to ensure that their quality of life is at least guaranteed to obtain the necessary goods and supplies. The value of zakat assistance needs to be re-evaluated based on current needs as the value of aid given is very small compared to current life needs. This includes taking into account the different needs and costs of living between urban and rural areas as well as the gender of the head of household.

Asnaf Fisabilillah in terms of a general definition means that the Islamic army is fighting against the infidels. However, debates and discussions on the definition of fisabilillah have occurred among scholars in the past and now lead to various ijtihad. There are scholars who try to take a new breath in interpreting the fee according to current requirements and in accordance with the sharia spirit and maqasid. Zakat institutions in Malaysia also have their own opinions and perspectives in defining the definition of Asnaf Fisabilillah (Rahman et al., 2016). According to Melaka Islamic Religion Council the definition of Asnaf Fisabillah is People who are struggling for their needs and program maslahah (interest) people - Muslims to spread Islam.

\section{Research Methods}

The objectives of the study to be achieved are:

$>$ To explain the form of distribution of Asnaf fisabilillah.

$>$ To explain the development of financial security by the government through the State Islamic Religious Council of Malacca.

Then the study was conducted using qualitative methods, based on two data, namely primary data obtained through interview method with officer division of the distribution unit. While secondary data is obtained from journals, articles and theses made through literature review. In order to obtain the primary data of the researcher using an interview approach that involves face-to-face interactions conducted between the researcher and officials at the distribution unit. During the 
INTERNATIONAL JOURNAL OF ACADEMIC RESEARCH IN BUSINESS AND SOCIAL SCIENCES

Vol. 10, No. 2, Feb, 2020, E-ISSN: 2222-6990 @ 2020 HRMARS

interview session, audio recordings were used as instruments in collecting research findings. Subsequently, audio recordings were examined for the content of the interviews and listened to repeatedly to be understood in depth and in line with the objectives of the study.

\section{Discussion and Results}

The results of this study are divided into two sections namely Distribution of Asnaf Fisabilillah and method of development of Asnaf Fisabilillah.

1. Distribution Asnaf Fisabilillah

Zakat distribution for fisheries is second highest in terms of zakat distribution, this is because these fisheries allowances are common, rather than individuals such as poverty and poverty because fisheries are concentrated on institutions, non-governmental organizations (NGOs). charity, religious programs, missionary activities and including orphanage management. Some of the forms of donations are available for educational purposes such as educational assistance, orphanage financing, mosque and missionary management, as well as donations to religious, welfare, and missionary activities. There is no limit on the amount allocated to non-governmental organizations (NGOs), most of which are programs aimed at social community development. Meanwhile, the distribution of mosques for mosque management was mainly for religious programs. In addition, for the distribution of education will be provided in the form of aids, one-off donations and scholarships including the aid of primary, secondary and tertiary students.

2. Asnaf Fisabilillah Development

Focus of the program is on human capital development, such as motivating programs especially for children as preparation for the exam. In addition, entrepreneurship, development programs to guide entrepreneurs who are interested in entrepreneurship.

\section{Conclusion}

Asnaf distribution is not in the form of individual distribution such as distribution to the poor, indebtedness or new converts to Islam, but it is common to the social interests of the Muslim community such as welfare programs, mosque management or orphanage management. Whereas in the development of this potential. The key focus of developing the human capital development program for young people in preparation for preparing the future generation is an important agenda that defines the direction and achievement of religious, national and national development goals. As such, mastery of science and moral excellence are essential at the heart of quality individuals and communities.

Distribution in Islam is considered good, however, the intended distribution should be Shariahcompliant with the maintenance of the five basic necessities of life (maslahat) as outlined by alShariah maqasid (Shariah objective) namely (a) religion (deen), (b) soul (nafs), (c) descent (nasl), (d) property (maal) and (e) intellect (aql). Outlined 3 priorities for the purpose of preserving the five aspects of life as follows:

i. basic needs (dharuriyat),

ii. pleasure / desire (hajiyyat), and

iii. perfection (tahsiniyyat).

The key to the preservation of the five al-Shariah maqasids begins with the fulfillment of the first priority, the dharuriyat. It covers the basic human needs of living on this earth - food, clothing, 
shelter and more. These first-rate requirements are basic and flexible based on place and time. The second priority of the hajiyyat, however, is not essential to the survival of the five basic principles laid down by the al-Shariah maqasid, but it is essential to eliminate the difficulties and obstacles in life. While the third priority is tahsiniyyat, it is only matters related to comfort or more aimed at complementing human life.

In the context of this study, The philosophy of zakat distribution is to ensure the survival of Muslims in the care of religion, soul, property, posterity and intellect. Therefore, there are two types of distribution: consumer distribution and productive distribution. Consumption distributions in the form of cash assistance schemes, facilities, food, health aid and so on are common expenses from an accounting perspective. However, productive distribution involves the provision of capital goods such as motorcycles, engines, vehicles, homes and infrastructure such as school buildings, educational institutions and facilities of physical and permanent nature. Any form of distribution that is implemented should be based on the dharuriyat, hajiyyat and tahsiniyyat priority frameworks to achieve the five maqasid al-Syari'ah.

Therefore, to create an efficient and efficient distribution system by updating the role of amil (zakat collector) which not only serves as a zakat collecting agent but also plays a role in helping to distribute zakat by distributing charity and giving zakat to the community. An information system should also be created by creating a complete and systematic database system. In addition, the distribution of zakat asnaf fisabilillah should be implemented with a productive distribution aimed at helping asnaf develop their economy. Asnaf distributions of fisabilillah are distributed in the form of micro financing to Asnaf to carry out economic activities, such as business and agriculture. In addition, all business activities are monitored to assist entrepreneurship development. The values and attitudes associated with religious beliefs within countries can affect both public policy settings as well as social behaviours and yet, they are not explicitly considered within mainstream development agendas. Yet, religion should be considered a positive and constitutive force that can be harnessed to improve the material lives of the poor.

\section{References}

\section{Interview \& Website}

Informant: Mr. Hj. Muhammad Dino Bin Md. Delan

Position: Assistant administrative officer (head of the Naziran unit) division of the distribution unit.

https://melaka-insider.com/2019/03/06/rm87-8-juta-kutipan-zakat-melaka-naik-25-9/ (link reached January 29, 2020).

\section{Book and Journal}

Ali, A. F. M., Ibrahim, M. F., Aziz, M. R. A., \& Johari, F. (2014). Konsep Dan Isu Had Kifayah, Kemiskinan Bandar Dan Jantina Dalam Pengagihan Zakat. Labuan E-Journal of Muamalat and Society, 8, 14-26.

Hairunnizam, W., Sanep, A., \& Mohd Ali, M. N. (2004). Kesan bantuan zakat terhadap kualiti hidup: Kajian kes asnaf fakir dan miskin. The Journal of Muamalat and Islamic Finance Research, 1(1), 151-166.

Haron, M. S., \& Rahman, R. (2016). Pengagihan Zakat Dalam Konteks Kesejahteraan Masyarakat 
INTERNATIONAL JOURNAL OF ACADEMIC RESEARCH IN BUSINESS AND SOCIAL SCIENCES

Vol. 10, No. 2, Feb, 2020, E-ISSN: 2222-6990 @ 2020 HRMARS

Islam: Satu Tinjauan Berasaskan Maqasid Al-Syariáh. Labuan E-Jurnal of Muamalat and Society, 10, 129-140.

Meerangani, K. A. (2017). Potensi Zakat Dalam Pembangunan Umat Islam di Malaysia. In Prosiding Seminar Antarabangsa Pembangunan Islam.

Tarimin, M. (2005). Zakat Menuju Pengurusan Profesional. Kuala Lumpur: Utusan Publication \& Distributors Sdn. Bhd.

Fahurruzi, M. F. (2019). Kajian Pembangunan Asnaf Fisabilillah Oleh Majlis Agama Islam Melaka. Kertas Projek Akhir, Fakulti Keilmuan Islam, Kolej Universiti Islam Melaka.

Patmawati Hj Ibrahim. (2008). Pembangunan Ekonomi Melalui Agihan Zakat: Tinjauan Empirikal. Jurnal Syariah, 16(2), 223-244.

Rahman, A. A., Basah, M. Y. A., Abdullah, M., Nooh, M. N., \& Fauzi., A. A. M. (2014). Keberkesanan Program Usahawan Asnaf Oleh Institusi Zakat Dalam Menginterpretasikan Keharmonian Ummah. In International Conference on Arabic Studies and Islamic Civilization (Vol. 2014, pp. 500-509).

Rahman, A. A., Omar, S. M. N. S., Som, H. M., \& Mokhtar, S. Z. (2016). Skim Agihan Zakat Kepada Asnaf Fi Sabilillah Mengikut Maqasid Syariah : Kajian di Selangor dan Pulau Pinang. In Muzakarah Fiqh \& International Fiqh Conference 2016 (pp. 1-6). https://doi.org/http://dx.doi.org/10.1016/j.jneumeth.2014.11.003

Ramli, M. R., \& Abdullah, L. (2016). Agihan zakat terus kepada asnaf: Analisis figh dan kedudukannya di Malaysia. Labuan E-Journal of Muamalt and Society, 1968(April), 30-56.

Wahid, Hairnunnizam, Ahmad, S., \& Kader, R. A. (2009). Pengagihan Zakat oleh Institusi Zakat kepada Lapan asnaf: Kajian di Malaysia. In Seminar Kebangsaan Ekonomi Islam (pp. 1-17).

Wahid, Hairunnizam, Ahmad, S., Ali, M., Nor, M., \& Rashid, M. A. (2017). Prestasi Kecekapan Pengurusan Kewangan dan Agihan Zakat: Perbandingan antara Majlis Agama Islam Negeri di Malaysia (Financial Management and Zakat Distribution Efficiency Performance: A Comparison among State Islamic Religious Council in Malaysia). Jurnal Ekonomi Malaysia, 51(2), 33-46. https://doi.org/10.17576/JEM-2017-5001-4. 